\title{
SEASONALITY OF VIRAL RESPIRATORY INFECTIONS IN SOUTHEAST OF BRAZIL: THE INFLUENCE OF TEMPERATURE AND AIR HUMIDITY
}

\section{Luiz Gustavo Gardinassi ${ }^{1}$, Paulo Vitor Marques Simas ${ }^{1}$, João Batista Salomão², Edison Luiz Durigon ${ }^{3}$, Dirce Maria Zanetta Trevisan $^{4}$, José Antonio Cordeiro ${ }^{5}$, Mauricio Nogueira Lacerda ${ }^{6}$, $* *$ Paula Rahal $^{1}$, Fátima Pereira de Souza $^{7}$}

${ }^{1}$ Universidade Estadual Paulista, Instituto de Biociências, Letras e Ciências Exatas, Departamento de Biologia, Ribeirão Preto, SP, Brasil; ${ }^{2}$ Faculdade de Medicina de São José do Rio Preto, Departamento de Pediatria e Cirurgia Pediátrica, Pediatria e Puericultura, São José do Rio Preto, SP, Brasil; ${ }^{3}$ Universidade de São Paulo, Instituto de Ciências Biomédicas, Departamento de Microbiologia, São Paulo, SP, Brasil; ${ }^{4}$ Faculdade de Saúde Pública, Universidade de São Paulo, São Paulo, SP, Brasil; ${ }^{5}$ Faculdade de Medicina de São José do Rio Preto, Departamento de Epidemiologia e Saúde Coletiva, São José do Rio Preto, SP, Brasil;

${ }^{6}$ Faculdade de Medicina de São José do Rio Preto, Departamento de Doenças Infecciosas e Parasitárias, Laboratório de Pesquisas em Virologia, São José do Rio Preto, SP, Brasil; ${ }^{7}$ Universidade Estadual Paulista, Instituto de Biociências, Letras e Ciências Exatas, Departamento de Física, São José do Rio Preto, SP, Brasil.

Submitted: March 21, 2010; Returned to authors for corrections: December 12, 2010; Approved: August 30, 2011.

\begin{abstract}
Viruses are the major cause of lower respiratory tract infections in childhood and the main viruses involved are Human Respiratory Syncytial Virus (HRSV), Human Metapneumovirus (HMPV), Influenzavirus A and B (FLUA and FLUB), Human Parainfluenza Virus 1, 2 and 3 (HPIV1, 2 and 3) and Human Rhinovirus (HRV). The purposes of this study were to detect respiratory viruses in hospitalized children younger than six years and identify the influence of temperature and relative air humidity on the detected viruses. Samples of nasopharyngeal washes were collected from hospitalized children between May/2004 and September/2005. Methods of viral detection were RT-PCR, PCR and HRV amplicons were confirmed by hybridization. Results showed 54\% (148/272) of viral positivity. HRSV was detected in 29\% (79/272) of the samples; HRV in $23.1 \%$ (63/272); HPIV3 in 5.1\% (14/272); HMPV in 3.3\% (9/272); HPIV1 in $2.9 \%$ (8/272); FLUB in 1.4\% (4/272), FLUA in 1.1\% (3/272), and HPIV2 in 0.3\% (1/272). The highest detection rates occurred mainly in the spring 2004 and in the autumn 2005. It was observed that viral respiratory infections tend to increase as the relative air humidity decreases, showing significant association with monthly averages of minimal temperature and minimal relative air humidity. In conclusion, viral respiratory infections vary according to temperature and relative air humidity and viral respiratory infections present major incidences it coldest and driest periods.
\end{abstract}

Key words: Viral Respiratory Infections, HRSV, HRV, Temperature, Relative Air Humidity.

\footnotetext{
*Corresponding Author. Mailing address: Department of Phisics - Instituto de Biociências, Letras e Ciências Exatas - University of São Paulo State - Cristóvão Colombo Street, 2265, 15054-000 São Jose do Rio Preto, SP, Brazil.; Tel.: +55-17-3221-2463.; E-mail: fatyssouza@ yahoo.com.br

* and **: These authors contributed equally to this work
} 


\section{INTRODUCTION}

Respiratory viruses are the most frequent cause of acute respiratory infections (ARI) in infants and young children, and important causes of hospitalization in developing countries (1). The respiratory viruses, particularly Human Respiratory Syncytial Virus (HRSV), Influenzavirus types A and B (FLUA and B), Human Parainfluenzavirus 1, 2 and 3 (HPIV 1, 2 and 3), Human Rhinovirus (HRV) and Human Metapneumovirus (HMPV) have been recognized as the most important pathogens involved in lower respiratory tract infections (LRTI) $(32,35,38)$. Frequency of viral detection in LRTI depends on many factors, such as sample management, disease severity, diagnostic methods and climatic season (34).

Several studies have reported that viral respiratory infections present seasonal patterns, which are more accentuated in regions with temperate climate rather than tropical climate (8). As an example, outbreaks of respiratory syncytial virus and influenza viruses occur in the winter season in regions with temperate climate (3).

Brazil is a country where several studies revealed viruses as the main causes of respiratory infections in Fortaleza, in Rio de Janeiro, in São Paulo and in Curitiba $(18,35,36)$, as reported by Arruda et al. (1). These viruses cause illness that can range from a brief upper respiratory tract infection, as a common cold, to a severe systemic illness, like bronchiolitis and pneumonia, resulting in death (11).

Large countries like Brazil possess a wide range of geographical areas, each one with unique climatic characteristics. Epidemiological studies from tropical regions indicate that factors as rainy seasons (34) or low air humidity (3), in addition to temperature, may influence respiratory viruses outbreaks. Global warming carries profound changes in Earth's climate, and major changes in the atmosphere and in the climate have a vast impact on the biosphere and the human environment (20). Consequently, climatic variations and extreme weather events also cause profound impacts on infectious diseases incidences. Infectious agents (such as protozoa, bacteria and viruses) are devoid of thermostatic mechanisms, and reproduction and survival rates are thus strongly affected by fluctuations in temperature. Temperature dependencies are seen in correlations between disease rates and weather variations over weeks, months or years, as well as in close geographic associations with key climatic variables and the distributions of important infectious diseases (28).

Knowledge of the trends and seasonality of respiratory viral infections in the community could be a first step to confer information for health care providers, to facilitate the implementation of strategies to prevent and minimize transmission, and also introduce early therapeutic options to high risk patients (13).

The aim of this study was to detect the presence of respiratory viruses in clinical samples collected from children with respiratory tract infection, and analyze the seasonal trends and occurrence patterns of the identified viruses.

\section{MATERIALS AND METHODS}

\section{Clinical Specimens}

This study was conducted at the Genomic Studies Laboratory of the Sao Paulo State University, located in Sao Jose do Rio Preto, São Paulo State, whose inhabitants reach the number of 402.770. Samples were collected at the Sao Jose do Rio Preto Base Hospital, a tertiary health care facility. Patients were children between one month and six years of age attended between May 2004 and September 2005, suffering from ARI. A single nurse was responsible for collecting the samples during the whole study. Nasopharyngeal washes were obtained after instillation of $0.5 \mathrm{ml}$ of sterile PBS (Phosphate Buffered Saline - $\mathrm{NaCl}, \mathrm{Na}_{2} \mathrm{HPO}_{4}, \mathrm{NaH}_{2} \mathrm{PO}_{4}$ ) into each nostril with immediate aspiration through a sterile neonatal canula inserted into the child's nasopharynx. The sample was transferred to a sterile vial and immediately transported to the laboratory, processed and frozen at $-86^{\circ} \mathrm{C}$ in Trizol LS 
(Invitrogen, Carlsbad, CA) for later RNA extraction and RTPCR testing. This method was chosen because of its high specificity and sensibility, besides being a rapid test for the identification of many pathogens, including respiratory viruses. This study was approved by Research Ethics Unesp/IBILCE by opinion $\mathrm{n}^{\circ}$ 062/2001 on June 11, 2001, in São José do Rio Preto, Brazil.

\section{RNA Extraction and cDNA Synthesis}

Viral RNA was extracted from $250 \mu 1$ of clinical specimen following the Trizol LS manufacturer's instructions and suspended in $20 \mu 1$ of MiliQ water treated with DEPC (diethylpyrocarbonate, Sigma, St Louis, USA), cDNA was synthesized using the High-Capacity cDNA Archive Kit (Applied Biosystems, Foster City, CA) utilizing random primers according to the manufacturer's protocol, and stored at $-20^{\circ} \mathrm{C}$.

\section{PCR amplification}

The amplification reaction of HMPV, FLU A and FLU B, HPIV1, HPIV2 and HPIV3 and HRV was performed in a final volume of $25 \mu \mathrm{l}$, with $3 \mu \mathrm{l}$ of cDNA, $5 \mu \mathrm{l}$ of buffer $(75 \mathrm{mM}$ Tris$\left.\mathrm{HCl} \mathrm{pH} \mathrm{9.0,} 50 \mathrm{mM} \mathrm{KCl}, 20 \mathrm{mM}\left(\mathrm{NH}_{4}\right)_{2} \mathrm{SO}_{4}\right), 3 \mu \mathrm{l}$ of $50 \mathrm{mM}$ $\mathrm{MgCl}_{2}, 1 \mu \mathrm{l}$ of $10 \mathrm{mM}$ dNTPs, $2.5 \mu \mathrm{l}$ of each primer (as per 6 , $12,14,21)$ at $10 \mathrm{pmol}(10), 0.5 \mu \mathrm{l}(2 \mathrm{U})$ of DNA polymerase (Biotools), and MilliQ water treated with DEPC. The reaction consisted of 40 amplification cycles with denaturation at $94^{\circ} \mathrm{C}$ for 45 seconds, annealing at $54^{\circ} \mathrm{C}$ for 45 seconds; extension at $72^{\circ} \mathrm{C}$ for 45 seconds, and final extension at $72^{\circ} \mathrm{C}$ for $7 \mathrm{~min}$. For Human Rhinovirus identification, the amplicons produced by PCR were confirmed through hybridization performed with OLP and OLE oligonucleotide probes as previously published (31).

HRSV amplification was made by a semi-nested PCR method which involves two steps. The first step resulted in final reaction volume of $50 \mu \mathrm{l}$, using $5 \mu \mathrm{l}$ of cDNA and a reaction composition identical to the one describe above for the other viruses. The reaction started with a denaturation step at $95^{\circ} \mathrm{C}$ for 5 minutes, followed by 40 cycles of $94^{\circ} \mathrm{C}$ for 1 minute, $55^{\circ} \mathrm{C}$ for 1 minute, $72^{\circ} \mathrm{C}$ for 1 minute, and a final extension step at $72^{\circ} \mathrm{C}$ for 7 minutes. The samples which were tested negative in this step were undergone a second round of semi-nested PCR. For the second round, $5 \mu \mathrm{l}$ of product from the previous reaction were mixed with $5 \mu 1$ of buffer and the same remaining components from the $1^{\text {st }}$ round, except for the use of $1.5 \mu \mathrm{l}$ of each primer at 10pmol (as per 20, 29, 30). The reaction was preceded by a denaturation step at $95^{\circ} \mathrm{C}$ for 5 minutes, followed by 40 cycles at $94^{\circ} \mathrm{C}$ for 1 minute, $55^{\circ} \mathrm{C}$ for 1 minute, $72^{\circ} \mathrm{C}$ for 1 minute, and an extension step at $72^{\circ} \mathrm{C}$ for 7 minutes.

The amplification products were analyzed in a $1.2 \%$ agarose gel stained with ethidium bromide, visualized under UV light.

\section{Statistical Analysis}

Statistical analysis was performed using the Minitab Statistical Software for Windows, version 12.22, and differences were considered significant if $\mathrm{p}<0.05$

\section{Geographical and Meteorological Data}

São José do Rio Preto is localized in Northwest of São Paulo State, which is one of the states composing the Southeast region from Brazil. The city is located at an average altitude of 489 meters, latitude of $-20,81972^{\circ}$ and longitude of $-49,37944^{\circ}$. São José do Rio Preto has a subtropical climate with an annual average temperature of $23,6^{\circ} \mathrm{C}$, composed by dry and cold winters, and rainy summers with increased temperatures. January and March generally are the warmer months of the year, and the average temperature is $27^{\circ} \mathrm{C}$. July is the coldest month, with an average temperature of $19,9{ }^{\circ} \mathrm{C}$. The autumn and spring are transition periods.

Data on temperature were supplied by the agriculture and supply secretary - represented by the Integral Technical Assistance Coordination - CATI - and collected from daily 
temperature measures made by the Seeds, Seedlings and Matrices Department of Seeds Production Nucleus from Sao Jose do Rio Preto. Data on relative air humidity were obtained from SOMAR Meteorology through daily measures of REDEMET (Air Command Meteorological Network) at Sao Jose do Rio Preto Airport.

\section{RESULTS}

During the period of study, 272 nasopharyngeal washes were collected from 272 children aged from1 to 68 months (average age of 29.5 months). From this total, $44.5 \%$ (121/272) were younger than 24 months and $57 \%$ were male (Table 1). Respiratory viruses were detected in $54.4 \%$ (148/272) of the samples, being HRSV the most detected consisting in $29 \%$ (79/272) from the positive samples. HRV was detected in $23.1 \%(63 / 272)$, HPIV3 in 5.1\% (14/272), HMPV in $3.3 \%$ (9/272), HPIV1 in $2.9 \%(8 / 272)$, FLUB in $1.4 \%(4 / 272)$, FLUA in $1.1 \%(3 / 272)$ and HPIV2 in $0.3 \%(1 / 272)$ (Table 1). From the 148 positive samples, $29.7 \%$ (81/272) were collected from male patients and $24.6 \%(67 / 272)$ were from female (Table 1).

Table 1. Association between detected respiratory viruses with age and gender (\%).

\begin{tabular}{|c|c|c|c|c|c|c|c|c|c|}
\hline Age/Gender & $\begin{array}{l}\text { Positive } \\
\text { Viruses }\end{array}$ & HRSV & HMPV & FLUA & FLUB & HPIV1 & HPIV2 & HPIV3 & HRV \\
\hline$\leq 24$ meses & $\begin{array}{c}61 / 121 \\
(50.5 \%)\end{array}$ & $\begin{array}{c}28 / 121 \\
(23.1 \%)\end{array}$ & $\begin{array}{c}7 / 121 \\
(5.8 \%)\end{array}$ & $\begin{array}{c}1 / 121 \\
(0.8 \%)\end{array}$ & 0 & $\begin{array}{c}2 / 121 \\
(1.6 \%)\end{array}$ & $\begin{array}{c}1 / 121 \\
(0.8 \%)\end{array}$ & $\begin{array}{c}7 / 121 \\
(5.8 \%)\end{array}$ & $\begin{array}{c}28 / 121 \\
(23.1 \%)\end{array}$ \\
\hline$>24$ meses & $\begin{array}{c}87 / 151 \\
(57.6 \%)\end{array}$ & $\begin{array}{c}51 / 151 \\
(33.8 \%)\end{array}$ & $\begin{array}{c}2 / 151 \\
(1.3 \%)\end{array}$ & $\begin{array}{l}2 / 151 \\
(1.3 \%)\end{array}$ & $\begin{array}{c}4 / 151 \\
(2.6 \%)\end{array}$ & $\begin{array}{l}6 / 151 \\
(4 \%) \\
\end{array}$ & 0 & $\begin{array}{c}7 / 151 \\
(4.6 \%) \\
\end{array}$ & $\begin{array}{c}35 / 151 \\
(23.2 \%)\end{array}$ \\
\hline Male & $\begin{array}{c}81 / 155 \\
(52.3 \%)\end{array}$ & $\begin{array}{l}38 / 155 \\
(24.5 \%)\end{array}$ & $\begin{array}{l}7 / 155 \\
(4.5 \%)\end{array}$ & $\begin{array}{l}2 / 155 \\
(1.3 \%)\end{array}$ & $\begin{array}{l}2 / 155 \\
(1.3 \%)\end{array}$ & $\begin{array}{l}4 / 155 \\
(2.6 \%)\end{array}$ & $\begin{array}{c}1 / 155 \\
(0.6 \%)\end{array}$ & $\begin{array}{c}8 / 155 \\
(5.2 \%)\end{array}$ & $\begin{array}{l}39 / 155 \\
(25.2 \%)\end{array}$ \\
\hline Female & $\begin{array}{c}67 / 117 \\
(57.3 \%)\end{array}$ & $\begin{array}{c}41 / 117 \\
(35 \%)\end{array}$ & $\begin{array}{c}2 / 117 \\
(1.7 \%)\end{array}$ & $\begin{array}{c}1 / 117 \\
(0.8 \%)\end{array}$ & $\begin{array}{c}2 / 117 \\
(1.7 \%)\end{array}$ & $\begin{array}{c}4 / 117 \\
(3.4 \%)\end{array}$ & 0 & $\begin{array}{c}6 / 117 \\
(5.1 \%)\end{array}$ & $\begin{array}{c}24 / 117 \\
(20.5 \%)\end{array}$ \\
\hline Total & $\begin{array}{l}148 / 272 \\
(54.4 \%)\end{array}$ & $\begin{array}{c}79 / 272 \\
(29 \%)\end{array}$ & $\begin{array}{c}9 / 272 \\
(3.3 \%)\end{array}$ & $\begin{array}{c}3 / 272 \\
(1.1 \%)\end{array}$ & $\begin{array}{c}4 / 272 \\
(1.4 \%)\end{array}$ & $\begin{array}{c}8 / 272 \\
(2.9 \%) \\
\end{array}$ & $\begin{array}{c}1 / 272 \\
(0.3 \%)\end{array}$ & $\begin{array}{l}14 / 272 \\
(5.1 \%)\end{array}$ & $\begin{array}{c}63 / 272 \\
(23.1 \%) \\
\end{array}$ \\
\hline
\end{tabular}

HRSV: Human Respiratory Syncytial Virus; HRV: Human Rhinovirus; HMPV: Human Metapneumovirus; HPIV3: Human Parainfluenzavirus Type 3; HPIV 1: Human Parainfluenzavirus Type 1; FLUB: Influenzavirus Type B; FLUA: Influenzavirus Type A; HPIV 2: Human Parainfluenzavirus Type 2.

The total respiratory infections were detected mainly in winter, spring and summer of 2004, and autumn and winter of 2005, as showed in Figure 1A, which also demonstrate the seasonal distribution of the detected respiratory viruses. Interestingly, the incidence of viral respiratory infections occurred between late winter and late spring 2004, with outbreaks occurring in spring. In contrast, the period of incidence in 2005 occurred between early autumn and late winter, with outbreaks in autumn.

Among all seasons that samples were collected, HRSV was the most identified virus, except for the summer 2005.
Outbreaks were observed in winter and spring 2004, and autumn 2005. Presenting similar results, HRV was also detected during the whole period of sample collection. Outbreaks were observed in winter and spring 2004, and autumn 2005 (Figure 1B).

HPIV3 and HMPV were detected in four of all seasons studied, being HPIV3 mainly detected in spring 2004 and HMPV in autumn 2005. HPIV1 had an incidence in two seasons, principally detected in spring 2004. FLUA, FLUB and HPIV2 presented incidences only in one season of the year, detected in winter and autumn 2005 respectively (Figure 1B). 
a)
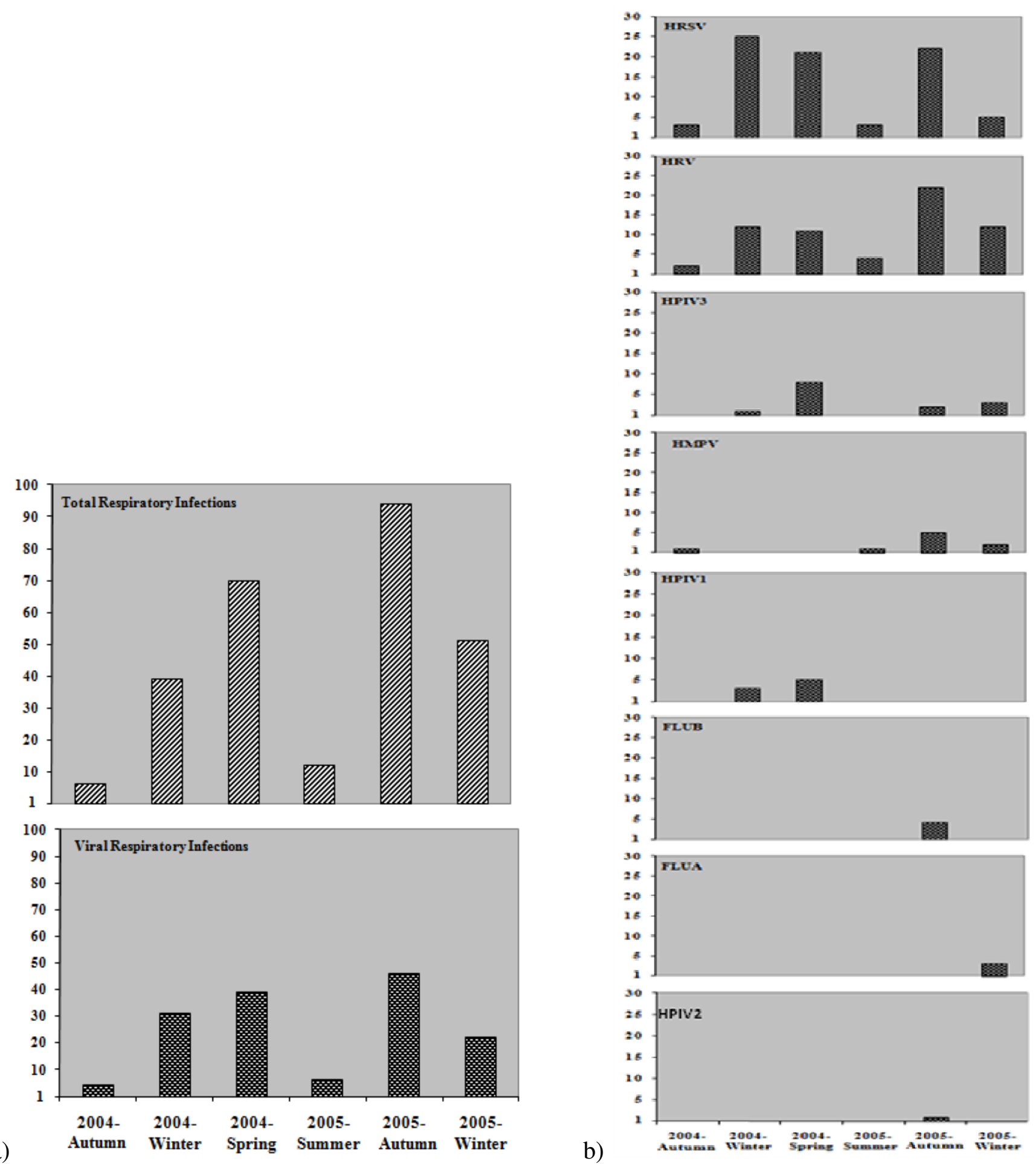

Figure 1. A: Distribution of total respiratory infections according to climatic season (total of collected samples of hospitalized children with respiratory infections) (above) and viral respiratory infections between autumn/2004 to spring/2005, distributed according to climatic season (below). B: Viral respiratory infections between autumn/2004 to winter/2005, demonstrating the seasonality of each isolated virus according to the climatic season. HRSV: Human Respiratory Syncytial Virus; HRV: Human Rhinovirus; HMPV: Human Metapneumovirus; HPIV3: Human Parainfluenzavirus Type 3; HPIV1: Human Parainfluenzavirus Type 1; FLUB: Influenzavirus Type B; FLUA: Influenzavirus Type A; HPIV2: Human Parainfluezavirus Type 2. 
The Figure 2 illustrates viral respiratory infections correlated to monthly average of relative air humidity and monthly average of temperature. In the beginning of autumn 2004, relative air humidity was $75 \%$ and respiratory viruses were detected in few samples. The results show that when relative air humidity and temperature begin to decrease, viral respiratory infections tend to increase; when the temperature and the levels of relative air humidity increase and are maintained relatively high (summer 2005), the detection rate of respiratory viruses decreases, evidencing strong influence of temperature and relative air humidity levels on the incidence of viral respiratory infections in this period. The influence of temperature and relative air humidity on the circulation pattern of respiratory viruses was evidenced by statistical analysis. Results present a significant association between viral respiratory infections and monthly average of minimal relative air humidity $(\mathrm{p}=0.046)$ as well as between the monthly average of minimal temperature $(\mathrm{p}=0.044)$. Therefore, it was evidenced that meteorological aspects may present influence one over the other, thus temperature tends to fluctuate according to characteristics of relative air humidity while the relative air humidity also varies according to the temperature.

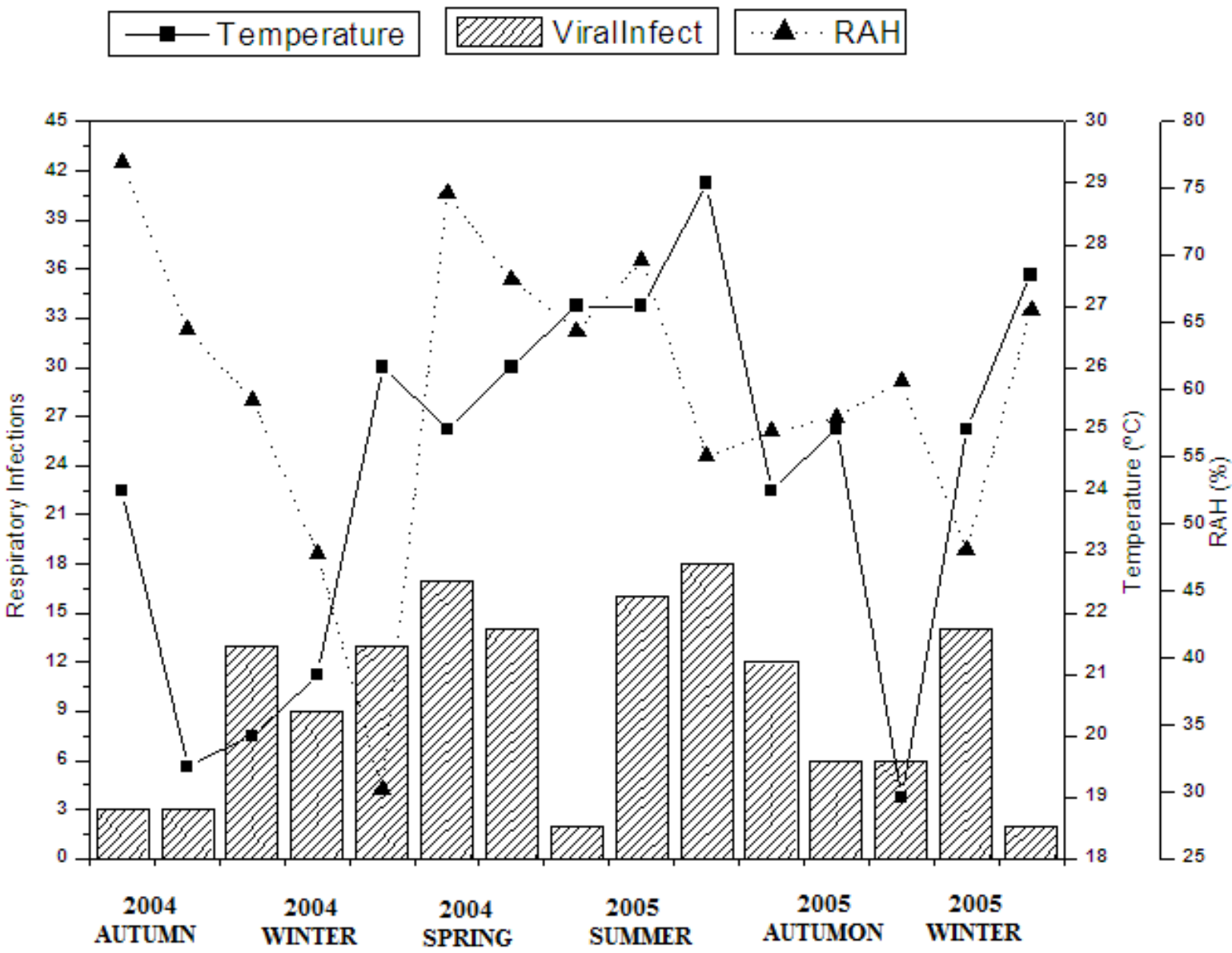

Figure 2. Correlation of viral respiratory infections to monthly average temperature and monthly average relative air humidity, showing the variation of infections according to the variation of the meteorological factors $\left[\mathrm{T}\left({ }^{\circ} \mathrm{C}\right)-\right.$ monthly average of temperature in ${ }^{\circ} \mathrm{C}, \mathrm{RAH}$ - monthly average of relative air humidity in (\%)]. 
Through a specific analysis of the relation between the positivity of each detected respiratory virus to the temperature and relative air humidity, it is possible to note that the major HRSV outbreak occurred in the period of lowest temperatures, in the winter of 2004. This data also shows an association statistically significant between HRSV circulation and monthly average of minimal temperature $(\mathrm{p}=0.010)$ (Figure 3$)$.

An interesting observation was made about data from
2005. There was an anticipation of HRSV infections, which occurred at higher rates in March and April - a transition between summer and autumn. In this period, there was a fluctuation of the average temperature, which dropped a few degrees, then increased for a short period of time and decreased again. We can also observe that HRSV infections in 2004 were more prevalent than in 2005, thus evidencing the influence of temperature on infections by HRSV.
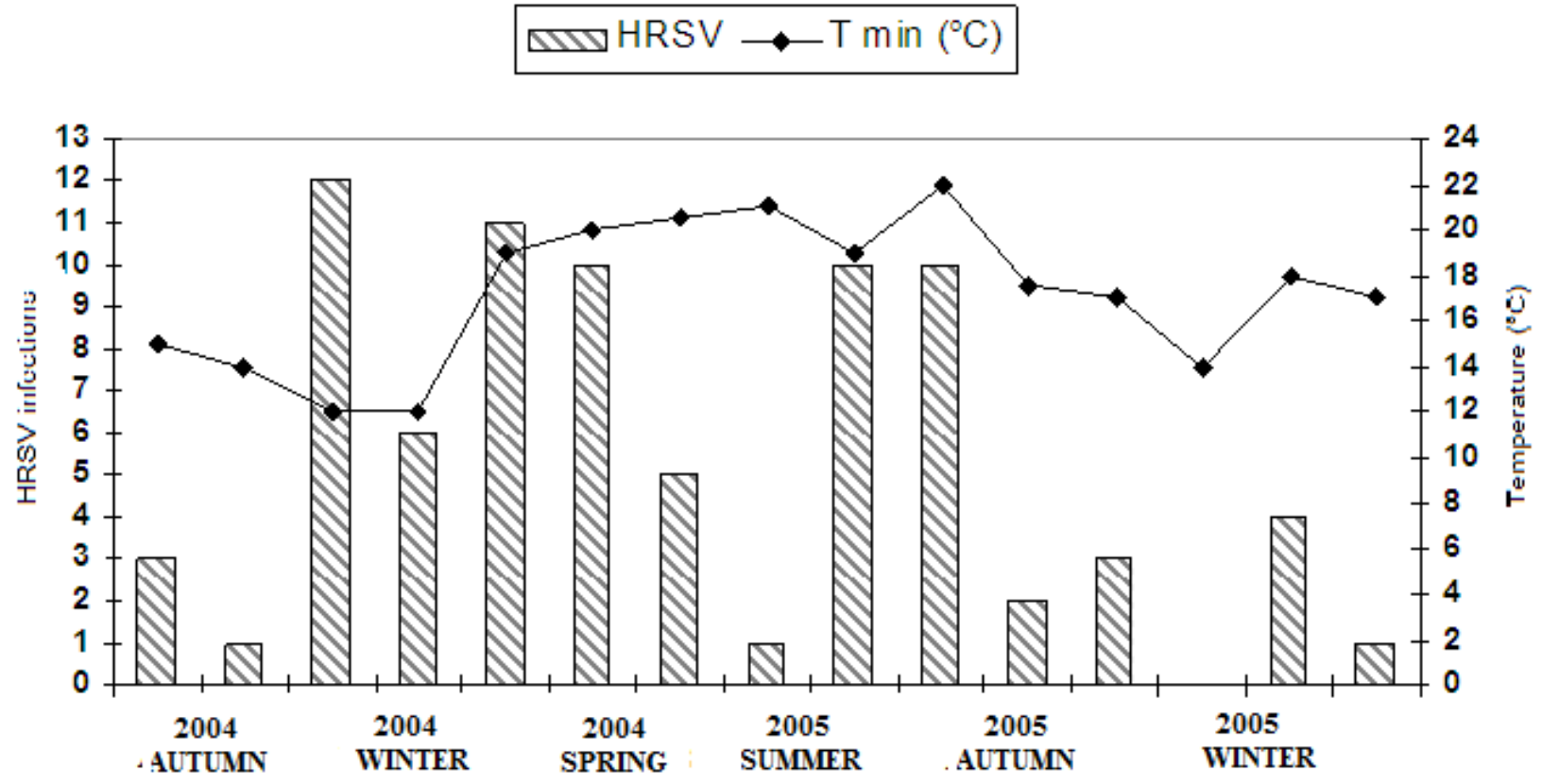

Figure 3. Association of HRSV infections to monthly average of minimal temperatures demonstrating the variation of infections according to the climatic season and variation of relative air humidity.

\section{DISCUSSION}

Acute respiratory infections (ARI) constitute a major factor in respiratory tract diseases, which are responsible for high rates of hospitalization and mortality. ARI accounts approximately for $20 \%$ of mortality in children up to 5 years old (30).

Respiratory viruses have been reported as the main cause of low respiratory tract infections in children $(3,11,38,39)$ living in emerging countries, and despite advances in the epidemiological knowledge of these infections, researches involving respiratory viruses features that circulate in countries as Brazil are still necessary.

From 272 samples collected from hospitalized children because of ARI, 54.4\% presented viral etiology. These data are in accordance with previous studies that reported respiratory 
viruses as the main cause of ARI, consisting of rates averaging from 30 to $75.5 \%(7,11,26)$.

There is knowledge that ARI, caused by viral infections, are influenced by a diversity of factors (34) and the mainly one observed on the present study was the relation between the detection of respiratory virus and climatic season, which presents differences in the meteorological factors of each season, including the variation of temperature and relative air humidity.

Before the prospect of anthropogenic climatic change emerged, epidemiologists were not greatly interested in climate-health relation (32). Recently, the discussions over the impacts of global warming on the terrestrial environment have awoken the interest of the association between climatic variations and health problems. Studies showed that the temperature-mortality relation varies greatly according to latitude and climatic zone. People living in warmer cities are more affected by lower temperatures, and people in colder cities are more affected by higher temperatures. In contrast, in the UK and some other northern high latitude countries, seasonal death rates and illness events are higher in the winter. (23).

In Brazil circulation of respiratory viruses shows different patterns according to region (7). In the Southeast region, which possesses a predominant subtropical climate, characterized by dry winters with moderate low temperatures and rainy summers, respiratory viruses have higher incidences in the coldest and driest months. Our results showed a significant association between viral respiratory infections and monthly average of minimal relative air humidity $(\mathrm{p}=0.046)$, and between monthly average of minimal temperature $(p=0.044)$. Therefore, it is observed that meteorological aspects may present influence one over the other, occurring variations on temperature according to fluctuations on relative air humidity, as relative air humidity varies according to temperature. These data reveal concomitant influences of climatic factors on viral respiratory infections. Consequently, the low temperatures and low relative air humidity could have effects on children respiratory tracts and immunological system, increasing their susceptibility to pathogens. Also these climatic profiles could cause an improvement of viral particles dissemination, leading to a higher probability of infection.

In the United States, the HRSV season has been documented to start in late December and end in late March with regional variability in average start time - ranging from late November and early January in the South and the Midwest, respectively (26). Compared to several other respiratory viruses which are primarily spread by droplets, the mode of transmission for HRSV is direct or indirect contact $(17,18)$. It has been suggested that human social behavior related to weather may increase person-to-person contact and may play a part in the seasonality of HRSV epidemics $(4,34)$. Crowding, large family size, multiple birth, and crowded homes are known risk factors for HRSV infection (2).

In Singapore rates of HRSV disease were associated with higher temperature, lower relative humidity and higher maximal day-to-day temperature variation (3). Weber et al. (1998) described a peak in HRSV-associated ALRI during the rainy season in The Gambia (39); however, earlier studies did not find such an association (15). Chan and colleagues reported HRSV disease to be directly associated with number of days of rainfall in a month and inversely associated with monthly mean temperature in Malaysia (4). The study, however, did not find an association between HRSV disease and total monthly precipitation (4).

On our study HRSV outbreaks presented defined seasonality, occurring in winter, early spring and late autumn periods, being these data similar to previous obtained results $(3,22,27)$. It is observed that there is a moderate fluctuation of temperature over the period of study (about $10^{\circ} \mathrm{C}$ ). Thus, it was verified a statistical significant association $(\mathrm{p}=0.010)$ between HRSV identification and monthly average of minimal temperature, showing that in Southeast Brazil this virus presents a correlation to periods that temperatures are lower. In 
contrast to our observations, Omer et al. (2008) observed an association of higher HRSV incidence with the increase of rainfall and temperature; however, it is necessary to consider that this study was performed on an island population, at sea level in a tropical equatorial region.

Concerning HRV, outbreaks were observed during spring, autumn and winter, agreeing to previous obtained results (7, 10), that detected HRV mainly in coldest months. Associating HRSV with HRV outbreaks, it was possible to verify that in 2004 HRSV had a major detection rate in late winter and spring; and comparing with the same period in 2005 it was verified that HRV had a higher prevalence, almost occurring an inversion on the incidences of these viruses in this period. An explanation for it would be the genotypes of HRSV circulating in 2004 and 2005. Children infected by HRSV in 2004 could obtain a better immune response to this virus in 2005, therefore leaving better conditions for HRV infections.

Knowledge about HMPV seasonality is limited in Brazil. Despite our results show a low percentage of HMPV detection, they agree with previous reported data $(5,16)$ showing this virus detection mainly in autumn; however, no significant statistical correlation to variations on temperature or relative air humidity was obtained.

The only positive sample to HPIV2 was collected during winter. HPIV1 and HPIV3 detection occurred mainly in late winter and spring. Similar results were reported $(5,26)$ showing this virus presence in samples collected in spring, autumn and winter. According to literature, HPIV3 are the most frequent viruses from this family, being type 1 and 2 viruses barely detected or even detected, which shows agreement with obtained results to literature data.

FLUA and FLUB were detected in few samples; however, these samples were collected during autumn and winter, agreeing to previous studies that showed Inlfuenza outbreaks occurring between late summer and early winter $(11,24,26)$.

The occurrence of these infections showed associations with the coldest and driest periods, represented by autumn, winter and spring seasons; however, the minimal temperatures are high when compared to those observed in countries of temperate climate where the seasonality is defined. Also there is a small variation on temperature throughout the seasons in regions of subtropical climate.

In conclusion, results obtained by the present study show that these pathogens have distinct seasonal patterns in São José do Rio Preto, which are especially influenced by meteorological factors, such as variations on temperature and relative air humidity. This is the first report showing those seasonal patterns of circulating respiratory viruses and their relation to climatic events in this city. Therefore, the results demonstrate the importance of epidemiological surveillance of respiratory viruses in all regions from Brazil, suggesting that future studies correlating clinical aspects to climatic variations are needed, principally concerning viral respiratory infections on Southeast region of Brazil.

\section{ACKNOWLEDGEMENTS}

To Fundação de Amparo à Pesquisa do Estado de São Paulo for the financial support (02/08461-2 and 04/06883-2 process) and Juliana Ribeiro for the samples collect.

\section{REFERENCES}

1. Arruda, E.; Hayden, F.G.; Mcauliffe, J.F.; Souza, M.A.; Mota, S.B.; Macauliffe, M.I.; Geist, F.C:, Carvalho, E.P:, Fernandes, M.C:, Guerrant, RL:, Jack, M.; Gwatelney, Jr. (1991). Acute respiratory viral infections in ambulatory children of urban northeast Brazil. J Infect Dis 164, 252-8.

2. Bulkow LR, et al. Risk factors for severe respiratory syncytial virus infection among Alaska native children. (2002) Pediatrics 109: 210-216.

3. Chew, F.T.; Doraisingham, S.; Ling, A.E.; Kumarasinghe, G.; Lee, B.W. (1998). Seasonal trends of viral respiratory tract infections in the tropics. Epidemiol Infect 121, 121-8.

4. Chan PK, et al. (1999) Epidemiology of respiratory syncytial virus infection among paediatric patients in Hong Kong: seasonality and disease impact. Epidemiology and Infection 123: 257-262.

5. Cintra, O.A.L.; Owa, M.A.; Machado, A.A.; Cervi, M.C.; Figueiredo, L.T.M.; Rocha, G.M.; Arruda, E.N. (2001). Ocurrence and severity of 
infections causes by subgroup A and B respiratory syncytial virus in children in southeast Brazil. J Med Virol 65, 408-12.

6. Class, E.C.J.; Sprenger, M.J.W.; Kleter, G.E.M.; van Beek, R.; Quit, W.G.V.; Masurel, N. (1992) Type-specific identification of influenza viruses A, B and C by the polymerase chain reaction. J Virol Methods, v. 39, p. 1-13.

7. Collins, P.I.; Chanock, R.M.; Murphy, B.R. (2001). Respiratory syncytial virus. In: Knipe, D.M.; Howley, P.M. Fields Virology. Philadelphia: Lippincott Williams \& Wilkins, p. 1443-86.

8. Costa, L.F.; Yokosawa, J.; Mantese, O.C.; Oliveira, T.F.M.; Silveira, H.L.; Nepomuceno, L.L.; Moreira, LS; Dyonisio,G;, Rossi, LMG; Oliveira, RC;, Ribeiro, LZG;, Queiroz;, DAO. (2006). Respiratory viruses in children young than five years old with acute respiratory disease from 2001 to 2004 in Uberlândia, MG, Brazil. Mem Inst Oswaldo Cruz 101, 301-6.

9. D'amato, G.; Cecchi, L. (2008). Effects of climate change on environmental factors in respiratory allergic deseases. Clin Exp Allergy $38,1264-74$.

10. Donaldson, G.C. (2006). Climate change and the end of the respiratory syncytial virus. Clin Infec Dis 42, 677-9.

11. Druce, J.; Tran, T.; Kelly, H.; Kaye, M.; Chibo, D. Kostecki, R.; Amiri, A., Catton, M.; Birch, C. 2005. Laboratory Diagnosis and Surveillance of Human Respiratory Viruses by PCR in Victoria, Australia, 2002-2003. J Med Virology 75: 122-9.

12. Echevarria, J.E.; Erdman, D.D.; Swierkosz, E.M.; Holloway, B.P.; Anderson, L.J. (2003). Simultaneous detection and identification of human parainfluenza viruses 1,2 and 3 from clinical samples by multiplex PCR. J Clin Microbiol v. 41, p. 4298-4303.

13. Estrada, B. Carter.; M, Barik, S.; Vidal, R.; Herbert, D.; Ramsey, K M. (2007). Humam Metapneumovírus Infection. Clin Ped (Phila), 46(3), 258-62.

14. Falsey, A.R.; Erdman, D.; Anderson, L.J.; Walsh, E.E. (2003). Human metapneumovirus infections in young and elderly adults. J. Infect. Dis. 187(5), 785-90.

15. Forgie IM, et al. (1991) Etiology of acute lower respiratory tract infections in Gambian children Pediatric Infectious Disease Journal 10: 33-341.

16. Galiano, M.; Videla, C.; Puch, S.S.; Martinez, A.; Echavarria, M.; Carballal, G. (2004). Evidence of human metapneumovirus in children in Argentina. J Med Virol 72(2), 299-303.

17. Goldmann DA. (2000). Transmission of viral respiratory infections in the home. Pediatric Infectious Disease Journal 19 (10 Suppl.): S97-102.

18. Hall CB, Douglas Jr. RG. (1981) Modes of transmission of respiratory syncytial virus. Journal of Pediatrics 99: 100-103

19. Kuiken, T.; Fouchier, R.; Rimmelzwaan, G.; Osterhaus, A. (2003). Emerging viral infections in a rapidly changing world. Curr Opin Biotechnol 14, 641-6.
20. Lee, J.T.; Chang, L.Y.; Wang, L.C.; Kao, C.L.; Shao, P.L.; Lu, C.Y.; Lee, P.I.; Chen, J.M.; Lee, C.Y.; Huang, L.M. (2007). Epidemiology of respiratory syncytial virus infection in northern Taiwan, 2001-2005 seasonality, clinical characteristics, and disease burden. J Microbiol Immunol Infect 40, 293-301.

21. Mazzuli, T.; Peret, T.C.; Mcgeer, A.; Cann, D.; Macdonald, K.S.; Chua, R.; Erdman D.D.; Anderson, L.J. (1999) Molecular characterization of a nosocomial outbreak of human respiratory syncytial virus on an adult leukemia/lymphoma ward. J Infect Dis, v. 180, p. 1686-1689.

22. Mcmichael, A.J.; Woodruff, R.E.; Halles, S. (2006). Climate change and human health: present and future risks. Lancet 367, 859-69.

23. Miyao, C.R.; Gilio, A.E.; Vieira, S.; Hein, N.; Pahl, M.M.C.; Betta, S.L.; Durigon E.L, Stewien K.E., Queiroz, D.A.O.; Botoso, V.F.; Gomes, M.C.S.; Lopes, C.L.B.C.; Ejzenberg, B.; Okay, Y. (1999). Infecções respiratórias em crianças internadas por doença aguda do trato respiratório inferior. J Pediatr 73, 334-44.

24. Moura, F.E.; Borges, L.C.; Portes, S.A.; Ramos, E.A.; Siqueira, M.M. (2003). Respiratory syncytial virus infections during an epidemic period in Salvador, Brazil. Viral antigenic group analysis and description of clinical and epidemiological aspects. Mem Inst Oswaldo Cruz 98, 73943.

25. Mullins JA, et al. (2003) Substantial variability in community respiratory syncytial virus season timing. Pediatric Infectious Disease Journal; 22: 857-862.

26. Nascimento, J.P.; Siqueira, M.M.; Sutmoller, F.; Krawczuk, M.M.; Farias, V.; Ferreira, V.M.J.; Rodrigues. (1991). Longitudinal study of acute respiratory diseases in Rio de Janeiro: occurrence of respiratory viruses during four consecutive years. Rev Inst Med Trop S Paulo 33, 287-96.

27. Omer SB, Sutanto A, Sarwo H, Linehan M, Djelantik IGG, Mercer D, Moniaga V, Moulton LH, Widjaya A, Muljati P, Gessner BD, Steinhoff MC. (2008). Climatic, temporal, and geographic characteristics of respiratory syncytial virus disease in a tropical island population. Epidemiol. Infect. 136, 1319-1327.

28. Patz, J.A.; Campbell-Lemdrum, D.; Holloway, T.; Foley, J.A. (2005). Impact of regional climate change on human health. Nature 438, 310-7.

29. Peret, T.C.; Hall, C.B.; Hammond, G.W.; Piedra, P.A.; Storch, G.A.; Sullender, W.M.; Tsou, C.; Anderson, LJ. (2000). Circulation patterns of group A and B human respiratory syncytial virus genotypes in 5 communities in North America. J. Infect. Dis 18, 1891-6.

30. Peret, T,C.T.; Hall, C.B.; Schnabel, K.C.; Golub, J.A.; Anderson, L.J. (1998). Circulation patterns of genetically distinct group A and B strains of Human Respiratory Syncytial Sirus in a community. J. Gen Vir 79, 2221-9.

31. Pitkäranta, A.; Virolainen, A.; Jero, J.; Arruda, E.; Hayden, F.G. (1997). Detection of Rhinovirus, Respiratory Syncytial Virus, and Coronavirus Infections in Acute Otitis Media by Reverse Transcriptase Polymerase 
Chain Reaction. Pediatrics 102(2), 191-5.

32. Souza, L.S.F.; Ramos, E.A.G.; Carvalho, F.M.; Guedes, V.M.C.R.; Souza, L.S.; Rocha, C.M.; Soares, A B.; Velloso, LF.; Macedo, ISF.; Moura, EA.; Siqueira, M., Fortes; S.; Jesus, CC.; Santiago, CMG.; Carvalho, AMS.; Arruda, E. (2003). Viral respiratory infections in young children attending day care in urban northeast Brazil. Pediatr Pulmonol 35, 184-91,

33. Stensballe LG, Devasundaram JK, Simoes EA. (2003). Respiratory syncytial virus epidemics: the ups and downs of a seasonal virus. Pediatric Infectious Disease Journal; 22 (2 Suppl.): S21-S32.

34. Straliotto, S.M.; Siqueira, M.M.; Machado, V.; Maia, T.M.R. (2004). Respiratory viruses in the pediatric intensive care unit: prevalence and clinical aspects. Mem Inst Oswaldo Cruz 99, 883-7.

35. Tsuchiya, L.R.R.V.; Costa, L.M.D.; Raboni, S.M.; Nogueira, M.B.; Pereira, L.A.; Rotta, I.; Takahashi, G.R.A.; Coelho, M.; Siqueira, M.M (2005). Viral respiratory infections in Curitiba, Southern Brazil. J Infection 51, 401-7.
36. Vieira, S.E.; Stewien, K.E.; Queiróz, D.A.O.; Durigon, E.L.; Torok, T.J.; Anderson, L.J.; Miyao, C.R.; Hein, N.; Botosso, V.F.; Pahl, M.M.; Alfredo. E.G.; Ejzenberg, B.; Okay, Y. (2001). Clinical patterns and seasonal trends in respiratory syncytial virus hospitalizations in São Paulo, Brazil. Rev Inst Med Trop São Paulo 43, 125-31.

37. Weber MW, Mulholland EK, Greenwood BM. (1998) Respiratory syncytial virus infection in tropical and developing countries. Tropical Medicine \& International Health; 3: 268-280.

38. Wolf, D.G.; Greenberg, D.; Kalkstein, D.; Shemer-Anvi, Y.; Givon-Lavi, N.; Saleh Kalkstein, D.; Goldberg, M.; Dagan, R. (2006). Comparison of Human Metapneumovirus, Respiratory Syncytial Virus and Influenza A Viurs Lower Respiratory Tract Infections in Hospitalized Young Children. Pediatr Infect Dis J 25, 320-4.

39. World Health Organization. Acute respiratory infections in children. [updated 2007 Sep 20] Available from: http://www.who.int/fch/depts/ cah/resp_infections/en 